\title{
Hungarian Women's Holocaust Life Writing in the Context of the Nation's Divided Social Memory, 1944-2014
}

\section{Louise O. Vasvári}

\begin{abstract}
In this paper, in commemoration of the seventieth anniversary year of 1944 in Hungary, I explore selected women's Holocaust diaries, memoirs, letters, and other less studied documents, such as recipe books, all written during the war, which can provide invaluable resources for understanding the experiences of the victims of war, by personalizing the events and helping to write the obscure into history. At the same time, such documents allow historical voices of the period to provide testimony in the context of the divided social memory of the Holocaust in Hungary today. I will first discuss several Hungarian diaries and "immediate memoirs" written right after liberation, among others, that of Éva Heyman who began writing her diary in 1944 on her thirteenth birthday and wrote until two days before her deportation to Auschwitz, where she perished. I will then discuss two recently published volumes, the Szakácskönyv a túlélélésért (2013), which contains the collected recipes that five Hungarian women wrote in a concentration camp in Austria, along with an oral history of the life of Hedwig Weiss, who redacted the collection. Finally, I will refer to the postmemory anthology, Lányok és anyák.

Elmeséletlen történetek ['Mothers and Daughters: Untold Stories'] (2013), where thirty five Hungarian women, some themselves child survivors, others daughters of survivors, write Holocaust narratives in which their mothers' lives become the intersubject in their own autobiographies, underscoring the risks of intergenerational transmission, where traumatic memory can be transmitted (or silenced) to be repeated and reenacted, rather than worked through.
\end{abstract}

Keywords: Hungarian Holocaust, War and Life Writing, Women's Diaries, Women's Memoirs, Recipe Books, Postmemory, Politics of Memory, Social Memory

Biography: Louise O. Vasvári, who received her M.A. and Ph.D. at the University of California in Berkeley, is Professor Emerita of Comparative Literature and of Linguistics at Stony Brook University. She has also taught in various visiting capacities, including at the University of California, Berkeley, at the Eötvös Loránd University and at the Central European University in Budapest, the University of Connecticut (Storrs), and the Université de Jules Verne (Amiens). Currently she teaches one course yearly in the linguistics department at New York University and is also Affiliated Professor in American and English Studies at the University of Szeged, Hungary. She works in medieval studies, historical and socio-linguistics, translation theory, Holocaust studies, and Hungarian Studies, all informed by gender theory within a broader framework of comparative cultural studies. Related to the Holocaust, she has published with Steven Tötösy, Imre Kertész and Holocaust Literature (2005), Comparative Central European Holocaust Studies (2009), and Comparative Hungarian Cultural Studies (2011). She has also published in Hungarian on memoirs of Hungarian women survivors (2009) and on women prisoner doctors (2012).

$(\mathrm{cc}) \mathrm{BY}$

ULIS D-Sente
New articles in this journal are licensed under a Creative Commons Attribution 4.0 International License.

This journal is published by the University Library System of the University of Pittsburgh as part of its D-Scribe Digital Publishing Program and is cosponsored by the University of Pittsburgh Press 
Vasvári, Louise O. "Hungarian Women's Holocaust Life Writing in the Context of the Nation's Divided Social Memory, 1944-2014." Hungarian Cultural Studies. e-Journal of the American Hungarian Educators Association, Volume 7 (2014): http://ahea.pitt.edu DOI: 10.5195/ahea.2014.139

\section{Divided Hungarian Social Memory: 1944-2014}

"Because memory, particularly historical memory, fails, unfailingly" (Remnick 2014)

In this the seventieth anniversary year of the Holocaust in Hungary, the FIDESZ government has launched a Holocaust Memorial Year, and, in fact, the session in which this paper was originally presented at the 2014 AHEA Conference was under their sponsorship (see http://holocaustmemorialyear2014.gov.hu). There have been a number of conferences and public memorial events held and much public debate in Hungary and abroad centering on the question of whether, as is stated in the Preamble of the new Constitution, Hungary lost its sovereignty when it was occupied by the Germans on March 19, 1944, or whether the Germans were allies who marched in. Related to this central question is to what degree Hungarians, collectively and individually, were complicit in the very rapid ghettoization and mass deportation of Hungarian Jewry, whereby all of Hungary outside of Budapest was rendered judenfrei within three months. The debate is centered on the regime's emlékezetpolitika ['politics of memory'] (which is defined as the political means by which the objective truth of events are remembered and recorded, mythified, or silenced). The memory conflicts in Hungary are being played out around two new state-sponsored memorials. The first is The Holocaust Memorial Museum and Education Center called the Sorsok Háza ['The House of Fates'], whose very name is considered an insult for many victims, and whose stated aim is to focus on child victims and on rescuers. The second is the perhaps even more controversial "Occupation Monument," erected overnight on July 19, 2014 on Szabadság Tér ['Freedom Square'], which depicts Hungary as the Archangel Gabriel, traditionally considered Hungary's own guardian angel, being attacked by the German eagle, suggesting that the Hungarian government bore no responsibility for what happened after the German Occupation and, indeed, that all Hungarians were victims (for a cogent overview of these current political controversies, see Laczó 2014, while for a defense of the symbolism of the monument see Prime Minister Viktor Orbán's open letter (2014), and on the critique of the aesthetics of the new monument, see György 2014).

It is not my aim here to discuss the mix of political, ethical, emotional and ideological passion that these forms of public memorialization have raised, in which the current government has been accused by a significant opposition, whose members include many academic historians as well as Holocaust survivors, of exculpatory rewriting of Hungarian history. In a broader context, it is worth remembering that a divided Hungarian historical memory, in which different communities have a common past but not a shared memory, did not suddenly flare up with the 2014 anniversary, nor is it particular to Hungary. For example, in the United States, a century and a half after the Civil War, many in the South are still taught - and the majority apparently believe - the inaccurate historical narrative that the main cause of the Civil War was not about slavery but a dispute over states' rights versus federal authority (Egan 2014). In regard to historical memory of World War II and the Holocaust in Europe see the excellent overview of research by Tim Cole (2002), who after trying to bring order to the conceptual haziness of terms like collective memory/public memory/national memory, addresses the question of what happens when there is a memory clash and subsequent alienation between private memory and public discourse in Europe. Tony Judt (2000) has shown in detail how the memory of wartime experience in continental Europe has been distorted through a kind of collective amnesia about the inconvenient fact that the majority of people in Hitler's Europe were not resistance fighters but that a minority actively collaborated and many millions more rather easily accommodated to 
Vasvári, Louise O. "Hungarian Women's Holocaust Life Writing in the Context of the Nation's Divided Social Memory, 1944-2014." Hungarian Cultural Studies. e-Journal of the American Hungarian Educators Association, Volume 7 (2014): http://ahea.pitt.edu DOI: 10.5195/ahea.2014.139

Nazi rule. Specifically to Hungary, Paul Hanebrink (2013: 183) outlines how, empowered by the landslide elections of 2010, Hungary's government has renewed its search for a "usable anticommunist past," while Csilla Kiss (2014) has discussed how post-communist countries in general have had the added burden of contending not only with their wartime history but also with the experience of communism, which later colored their assessment of the former. Similarly, Georges Mink and Laure Neumayer in their History, Memory and Politics in Central and Eastern Europe: Memory Games (2013) have studied how, in post-communist countries twenty years after the end of Communism, contested memories about both Communism and World War II are constantly reactivated. The subtitle of their book, Memory Games, implies that recent attempts by governments in the new Eastern member states of the European Union and NATO to revise history are due to motives that are at once nationalistic, that is, seeking to whitewash the stain of collaboration with Hitler and a means to construct histories of pure national victimhood, with the aim of equating Soviet and Nazi atrocities. Mink and Neumayer end their Introduction with a pessimistic note about the possibility of achieving a more honest reckoning with the past in such a politically-loaded climate: "Until it is understood that the East's memory games have a specific content linked to the Second World War and Sovietization, there can be no successful "Europeanization" of the histories of Europeans" (22).

With regard specifically to Hungary, Tim Cole (2003: 221-249) studied the denial of the Holocaust by both the post-World War II communist regime, as well as by the subsequent postcommunist regime, while Professor Randolph Braham (2004a) - the uncontested dean of the historiography of the Hungarian Holocaust - has called the official emlékezetpolitika of postwar regimes a whitewashing of the past and a campaign of history falsification. ${ }^{1} \mathrm{He}$ added that one of the major means by which history cleaners aim to unburden the national conscience is by focusing on the rescue activities of the relatively small number of Hungarians recognized as Righteous Among the Nations. Braham (2004b) also points out that it is almost impossible to determine how many Jews were saved by Christians for payment or for humanitarian reasons. It must also be pointed out, however, that it is also true that many of those who were persecuted and survived almost inevitably did so with the aid of rescuers, as in the example of two recent memoirs testifying to such efforts, discussed in Marta Fuch's (2012) testimony to how her father, a munkaszolgálatos ['Hungarian army Labor Service draftee'] for five years in Ukraine, was saved, along with another one hundred Hungarian Jews, by his Commanding Officer, Zoltán Kubinyi, a devout Seventh Day Adventist (discussed by the author at the 2012 AHEA Conference in her presentation, "Hungarian Holocaust Legacy: A Daughter's Tribute to Her Father's Rescuer"); and in Zsuzsanna Ozsváth's wartime memoir of her childhood, When the Danube Ran Red (2010), wherein her family was saved through the incredible courage of the

\footnotetext{
${ }^{1}$ On the knowable historical facts, see most recently the well-documented Vági, Csösz and Kádár collection (2013). See also Rényi (2011) for a concise overview of Braham's views on the falsification of history and its causes in extreme nationalism. Cf. Tim Cole (2001), who reassesses the opinions of historians Braham, Deák, and Vera Ránki, on how much is due to the German invasion and how much of collaboration etc. Braham assumes that, prior to the Nazi occupation, 63,000 Hungarian Jews were killed within Hungary's enlarged borders, among them approximately 20,000 so-called alien Jews were expelled and murdered, and another 42,000 military-age Jewish males in labor battalions. After the Arrow Cross came to power in October, 1944, the capital Jews were placed in a closed ghetto and in the winter hundreds were shot into the Danube.
} 
Vasvári, Louise O. "Hungarian Women's Holocaust Life Writing in the Context of the Nation's Divided Social Memory, 1944-2014." Hungarian Cultural Studies. e-Journal of the American Hungarian Educators Association, Volume 7 (2014): http://ahea.pitt.edu DOI: 10.5195/ahea.2014.139

children's former nanny, Erzsi, who was adopted after the war by Ozsváth's father (reviewed in this journal in 2011 by Evie Blaikie).

Historical facts are fragmentary in nature and inherently prone to distortion, as Timothy Cole sought to show in his invaluable Traces of the Holocaust: Journeying in and out of the Ghetto (2011: 141), where he documented how the Hungarian Holocaust appeared as a dispersed event that involved a large number of different actors with diverse experiences, who sought to adapt to the rapidly changing circumstances (see the cogent review of Cole's volume by Laczó, 2013). Cole also showed the deep involvement of Hungarian society in events of the Holocaust, as well as the importance of money as a prime motive for the persecution of Jews, so that once their wealth/property had been expropriated Jews could be handed over to the Germans (cf. Ungváry 2013 on the implementation of Jewish Laws in Hungary being considered by rightwing politicians as a socio-political issue). In a recent interview Szabolcs Szita (Dömötör 2014), the former director of the Holocaust Center in Budapest, also discussed the various forms of plunder by the state of its Jewish citizens, from the official vagyonelkobzás ['wealth confiscation'], to the subsequent fosztogatások ['acts of plunder'] by the masses of belongings of deported Jews from their homes and from the ghettos, to the so-called official zsidó-vagyonkiárusitás ['selling off of Jewish belongings'] from October 15, 1944. From all of this experience emerged after the war the following joke among survivors: "How are you, asks the gentile from the returning Jew. - Don't ask, replies the Jew, I've got nothing left besides what you have on!' [Hogy vagy, kérdezi a nem zsidó a zsidó hazatéröt? -Ne is kérdezd, mondja amaz, semmim sem maradt azon kívül, ami rajtad van!].

It is precisely by recovering individual fragmentary histories, which personalize events in ways that other sources cannot, and by writing "the obscure into history," that social history from the micro-historical vantage point of the victims of the Hungarian Holocaust can be better recovered. My aim, following some of the tenets of Alltagsgeschichte ['everyday history'] (Lüdtke 1989) is to reconstruct the historical experiences of everyday life and the mentalities of such kleine Leute ['ordinary people'], the nameless in history, to give back a human face to the victims and to provide further details for a more complete picture of the Holocaust. Diaries and other diverse and less studied documents, including letters, passes, photographs, reports, and recipes, provide invaluable resources for understanding the experiences of the victims of war; it is in order to provide additional examples of such fragmentary histories for better understanding of the Hungarian Holocaust that I provide examples below of these discourses. ${ }^{2}$ Note in this contexts that scholars and writers in the Warsaw ghetto understood the importance for future understanding of such material testimony, which is why historian Emanuel Ringelblum (19001944) organized a secret operation code-named project Oyneg Shabbos [Yid.: Sabbath/Saturday Joy/Pleasure], carried on for almost three years, to collect individual diaries and other relics of everyday life, such as programs of school plays, copies of Nazi posters and decrees, maps of the

\footnotetext{
${ }^{2}$ On the importance, for example, of photographs for retrieving Holocaust events, which is a discourse that I am not able to discuss here, see also Karsai. (n.d.) and Karsai and Szabolcs (1992) on documents and photographs that testify to efforts to annihilate Hungarian Jews, which were items not destroyed at Budapest SS Headquarters and the Soviets later stored them in the basement of the Hungarian Ministry of Interior. The documents remained unseen for over forty years, but after 1989 they were given to the Jewish Museum and Archive of Hungary. On Holocaust photographs more broadly see Zelizer (1998).
} 
Vasvári, Louise O. "Hungarian Women's Holocaust Life Writing in the Context of the Nation's Divided Social Memory, 1944-2014." Hungarian Cultural Studies. e-Journal of the American Hungarian Educators Association, Volume 7 (2014): http://ahea.pitt.edu DOI: 10.5195/ahea.2014.139

ghetto, and other ephemeral objects, which were loaded into metal milk cans and tin boxes and buried under the ghetto's building, as a way to self-archive life in the Warsaw ghetto. The achievement of the members of Oyneg Shabbos in the face of their own all but certain annihilation testifies to a creativity that resisted silence and to the hope that these objects would serve in the future as traces of those who perished and would thus help write the history of their doomed community and of horrors that otherwise nobody would believe (Kassow 2007).

As the title of this paper indicates and as I have also discussed in earlier studies, my primary focus is on women's Holocaust testimonies within a gendered frame of analysis, specifically to examine the still relatively neglected role of gender differences generally in wartime, and specifically the important role of women's life writing in the history of the Holocaust, where, in fact, women have written considerably more than have men (Vasvári 2006, 2009a, b). While the best-known scholars of the Holocaust tend to focus more on the macro level, it has been women scholars, usually feminists, who analyze the Holocaust in terms of women, gender, children, and family life. Recovering women's voices and making women's experiences visible lends important new understanding to different experiences by men and women due to their different assigned gender roles as well as to gender-specific traumas suffered by victims. In such an analysis it is also important to take into account the intersection of gender, age, social class, and level of religious observance, as well as urban or provincial residence of the victims, all essential components of how men and women experienced the Holocaust, as is their manner of interpreting and narrating events. As Tim Cole (2006, 2011: 19-21, 59n43) documents, while during the earlier series of ever harsher anti-Jewish legislation in Hungary from 1942 to 1943, it was thousands of males between twenty and forty who were most at risk and the first to die in munkaszolgálat, where the level of mortality was $85 \%$ to $90 \%$, and where Jewish casualties were not considered as heroic war dead, their families received no compensation, nor were they exempt from ghettoization and deportation (see below the diary of Susan Kaszás, who describes a scene of forced laborers actually watching their families being deported). However, by the summer of 1944, while ghettoization and deportation were already taking place, gender vulnerability was drastically changed when, due to a general labor shortage, hundreds of Jewish males between 18 and 48, especially those with expertise, like doctors, engineers, and pharmacists, were conscripted for forced labor both from cities and ghettoes, thus ironically "saving" some of them from deportation, at least for a while (see Löwy 2010 on the commander Imre Reviczky, who saved many hundred men from deportation by calling them up even from ghettos). Only on Nov 2 and 3, 1944 were Jewish women living in Budapest called up by the Arrow Cross government, increasingly desperate for labor (see below the memoir of Borbála Szabó, who describes in some detail her experience in the female munkaszolgálat). Cole concludes that while men started dying earlier, ultimately it was women who constituted probably more than half the victims, and that those deported were primarily women, the elderly, and children from provincial Hungary, who were seen as dispensable. Ilana Rosen (2012) points out that the dozens of memoirs of male survivors of the munkaszolgálat, the communal memory books created by their former landsmanschaften ['immigrant communal organizations'] and 
Vasvári, Louise O. "Hungarian Women's Holocaust Life Writing in the Context of the Nation's Divided Social Memory, 1944-2014." Hungarian Cultural Studies. e-Journal of the American Hungarian Educators Association, Volume 7 (2014): http://ahea.pitt.edu DOI: 10.5195/ahea.2014.139

interviews with them have received no academic attention. ${ }^{3}$ Rosen, who conducted life history interviews in Budapest and Israel, found that, although statistically the mortality rates in labor service were as high as in the Nazi death camps, the prisoners still felt they had more of a chance to be in control of their lives and to strive for survival through escape or other means.

\section{Hungarian Women's Diaries and Immediate Memoirs of 1944}

As stated in the introductory section, I will be discussing examples of several categories of Hungarian women's wartime life writing as testimonies of the Holocaust, complementary to historical studies. I will not delve here into the complex (and very discipline-driven) discussions about the legitimacy of forms of life writing as historical documents. Nevertheless, such arguments might briefly be summarized through the contrasting views of four scholars. Raul Hilberg in his 1,300 page The Destruction of European Jews (1985) dismissed oral history and testimony for inaccuracies, seeing a dichotomy between history and memory, classifying the latter as a form of poetry and narrative. On the other hand, it was the historical veracity of diaries that James E. Young (1987: 420) considered of dubious value since, because they were written from within the events, their accounts can be mistakenly perceived to be stronger than those written later. In contrast to Young's views, Lawrence L. Langer, who in his Holocaust Testimony: The Ruins of Memory (1991: xii-xiii) studied oral testimonies, which he claimed allowed for "unshielded truth," questioned the legitimacy of the written memoir, whose style and language he felt could deflect from dreadful events. But as René Girard (1963: 10) cogently argued considerably earlier, a diary is not to be read like a news report but understood as a human voice reflecting an exterior landscape, an evaluation that could be extended to other forms of life writing, as well.

As David Patterson (2004) discusses, the two principal categories of autobiographymemoir and diary - both as historical documents and as "human outcries" must be read and understood differently, with, for example, even diaries written in hiding differing from those written in a ghetto or camp. Diaries are among the most personal and immediate accounts of life in the Holocaust, recording the day-by-day unfolding of horrible events in the life of the author, yet often with mundane, idealistic and naïve details of daily life included. As we have already seen in the case of the Warsaw Ghetto, where people of all ages and genders were writing diaries, written in terror, a diary can serves as a form of moral resistance to annihilation. The diary does not allow for perspective and distance but because it is normally written for the self it allows for the development of private sentiments not suitable for public scrutiny, as exemplified by the diaries discussed below, where teenage girls discuss their sexuality and a young wife claims that the psychological suffering she suffered from her mother-in-law was worse than her life in Auschwitz. Authors of Holocaust diaries, however, often expressed many sentiments beyond the private, sometime sensing — as did Anne Frank most famously — that they were

\footnotetext{
${ }^{3}$ See Horváth (2014) for one interesting example of communication of one munkaszolgálatos to his wife with a photograph and postcard. For a particularly beautiful memoir about the labor service, see Schwarcz (2005), who wrote down in 1965 his experiences in seven different labor service camps, followed by five concentration camps. Nevertheless, Schwarcz vowed that if he survived he would endeavor to live a life without hatred and vengeance. He lived on for sixty years, to the age of ninety-six. See Szabolcs (1998) and Szele and Szele (2004) for two examples of survivor male life writing about the labor service.
} 
Vasvári, Louise O. “Hungarian Women's Holocaust Life Writing in the Context of the Nation's Divided Social Memory, 1944-2014." Hungarian Cultural Studies. e-Journal of the American Hungarian Educators Association, Volume 7 (2014): http://ahea.pitt.edu DOI: 10.5195/ahea.2014.139

writing for posterity. The diary has often been traditionally excluded from both history and traditional literary studies because of its presumed looseness and lack of rigor. The memoir, in contrast to the diary, is a later reframing of the story, allowing for reflection and historical context to produce a more coherent text. Note, for example, in this context that Anne Frank, who hoped to become a writer after the war, undertook to rewrite her diary while in hiding, with the aim of turning it into a historical document, and compare also the extraordinary case of Margit K., discussed below, where the reader can follow how she turned her factual Holocaust diary into an ironic memoir immediately after Liberation. Retrospectively, however, both diary and memoir can be reframed by readers as historical archives, literary works, sacred documents, criminal evidence, cultural artifacts, etc., and it is in all these senses that I offer the few selections from the works I catalogue briefly.

The American feminist Adrienne Rich has called the diary "the profoundly female and feminist genre" (Huff 1999: 6), and indeed, although persons of all ages and backgrounds have written diaries, many more females, and especially teenage girls, have kept diaries than have males. In the culture of pre-World War II Europe it was very common for middle class girls to get a diary on their thirteenth birthday, as did Anne Frank, who received her red checkered diary in 1942, a few weeks before she and her family went into hiding. Anne Frank perished before her sixteenth birthday but her diary became her legacy and the single best-known Holocaust text worldwide. There exist many surviving Holocaust diaries by girls and young women in Hungarian as well, but none have become canonized in or out of Hungary or even taught in schools in Hungary. I will discuss several here, including one by one teenager, Éva Heyman, who like Anne Frank, perished in Bergen Belsen, very possible on the very same day as Anne Frank. ${ }^{4}$

Diaries like Éva Heyman's and Lilla Ecséri's, below, are, like that of Anne Frank, as much stories of precocious and artistically creative adolescence as about the Holocaust, but this adolescence is culturally shaped by historical conditions (Schwarz 1999: 110). For all three girls continuous writing into their diary was a survival strategy, and for a while in spite of Jewish laws all attempt to live a normal life, writing about family conflicts, quarrels with friends, flirtations, budding sexuality, adolescent longing for love and moodiness, personal identity, and hopes for the future. But while Anne Frank's diary, written in hiding, is less than twenty percent about the plight of the Jews, and much more about the unfolding of an adolescent girl's maturation, Éva Heyman's diary presents a much more painful and tragic perspective. Éva lived in Nagyvárad/Oradea/Grossvardein and was first confined there in the ghetto, which was second in

\footnotetext{
${ }^{4}$ Since my focus here is on the events of 1944 in Hungary, I will not discuss the diary of Anikó Szenes (Hannah Senesh) (1921-1944), whose Hungarian diary up to her departure from Hungary for Palestine in 1939 testifies to a surprisingly normal middle class Jewish world that continued to exist in Hungary, while the rest of Europe's Jewry was being decimated (Senesh 2004, Vasvári 2006). Nor will I discuss the Hungarian-language diary of Zimra Harsányi (later known as Ana Novac), born, like Éva Heyman, in Nagyvárad, Transylvania in 1929, who began to write her diary in Auschwitz about her camp experiences and briefly about her postwar return to Transylvania (Vasvári 2009b: 5). It is interesting that although both Szenes and Harsányi wrote in Hungarian, both became public symbols elsewhere: the first mythologized and canonized by Israel under the name Hanna Senesh as a national heroine; the second, although she wrote in Hungarian, was claimed by Romania as their Anne Frank, but both remain essentially unknown in Hungary.
} 
Vasvári, Louise O. "Hungarian Women's Holocaust Life Writing in the Context of the Nation's Divided Social Memory, 1944-2014." Hungarian Cultural Studies. e-Journal of the American Hungarian Educators Association, Volume 7 (2014): http://ahea.pitt.edu DOI: 10.5195/ahea.2014.139

size only to that in Budapest. She was then deported, as was the rest of Hungarian Jewry living in the countryside, and like some $95 \%$, she did not return, nem jött vissza, as euphemistically phrased by many survivors and their relatives. Lila Ecseri lived in Budapest during the summer of 1944, when Jews were confined in ghetto houses, and she worked in munkaszolgálat and later went into hiding, but like a significant number of Jews in Budapest, she did manage to avoid transport to Auschwitz and thus survived.

Éva Heyman (1931-1944) was from a secular bourgeois family, the only child of divorced parents, who lived with her grandparents and was primarily raised by her beloved gentile Austrian governess, Justi. She began, like many girls of her class, writing in her journal on her thirteenth birthday, on February 13, 1944, and continued until her last scribbled entry on May 30, two days before her deportation, writing that she was hurrying to meet Mariska, the family cook, presumably to confide her diary to her. Unlike Anne Frank, who was able to continue writing in hiding for more than two years and was able to revise her work, Éva wrote for only three and a half months, one month of which was spent in the ghetto. Much as Anne Frank decided to call her diary Kitty, Éva called hers kis naplóm ['my [beloved]? little diary'], her best friend. Though she confessed that she often "didn't understand" the exact implications of the events she mentioned, she nevertheless touched on major historical currents as they affected her immediate family and friends, showing her increasing social and political awareness. Éva's hometown of Nagyvárad (part of Romania since 1919) was returned to Hungary in 1940, and she describes the humiliating consequences for her grandfather, whose pharmacy was expropriated. While she writes about her crush on Pista Vadas, an older boy, she also declares her intention several times to marry an Aryan Englishman, someone as un-Jewish as possible. She also writes about the conscription of her stepfather, the well-known author Béla Zsolt, into munkaszolgálat. But, most importantly, almost functioning as a leitmotif in her writing are the traumatizing events of the deportation in 1941 to, as she says, "Poland" of Márta Münzer, her good friend two years her senior. Éva returns again and again in her diary to the memory of three years earlier when her friend was deported, seeing it as a premonition of her own fate. Although Márta, her mother, and her grandfather were born in Hungary, because her father was born in Bukovina (when both it and Hungary were still part of the Austro-Hungarian Empire), the whole family was among 16,000 people declared aliens or with unresolved citizenship status. These people were deported in July and August 1941 from Nagyvárad by the Hungarians, without luggage and without food, to territories under German rule in the vicinity of KamenetzPodolskyi, Galicia, where they were turned over to the SS to be massacred; in retrospect these killing events were seen as one of the preludes to the Holocaust in Hungary (Braham 1981: 199207, 211). Éva recounts in her diary how, when Márta is urgently called home from an afternoon at Éva's house because the police are there, the poor girl naively thinks that she is going to be punished for riding her bicycle too fast, but in fact she and her family are about to disappear forever ("Éva Heyman on the deportation of her friend, Márta, from Hungary, at www.yadvashem.org):

Márta was over at our house. First we went riding our bicycles in Szálldobágy. That was my first 'tour' on this bicycle. Márta's was just like mine, only hers was a brighter red. Then we came home, and Ági [Éva's mother] asked Márta to dance something to music from a record but Márta didn't want to because she was tired from riding the bicycle. Then we had an afternoon snack, chocolate with whipped cream and strawberries with whipped cream, which Márta loved more than 
Vasvári, Louise O. "Hungarian Women's Holocaust Life Writing in the Context of the Nation's Divided Social Memory, 1944-2014." Hungarian Cultural Studies. e-Journal of the American Hungarian Educators Association, Volume 7 (2014): http://ahea.pitt.edu DOI: 10.5195/ahea.2014.139

anything else, even dancing. Suddenly the bell rang at the front gate five times. It was Márta's nursemaid who had stayed on with them as a cook because Márta didn't need a nursemaid anymore. She came and said: "Mártika, come home. The police are there, and you have to go with Papa and Mama." I still remember Ági. She turned white as the plaster on the wall. But Márta said it must be because she rode her bicycle so fast on Rimanóczi Street, and her father had said many times that she would end up at the police on account of "speeding" (Zsolt 1947: 13-14).

[Márta itt volt nálunk elöbb Szálldobágyon, voltunk biciklizni, ez volt az első "túrám" ezzel a piros biciklivel, Mártáé pont ilyen volt, csak világosabb piros. Aztán hazajöttünk és Ági kérte Mártát, hogy táncoljon a gramofonra valamit, de Márta nem akart, mert fáradt volt a biciklizéstöl. Később uzsonnáztunk, csokoládét habbal és epret habbal, azt Márta a világon a legjobban imádta, még a táncnál is jobban. Egyszer csak a kapunál ötöt csengettek, Márta dadája volt, aki ott maradt szakácsnönek náluk, mert Mártának már nem kell dada és azt mondta: "Mártika, gyere haza, ott vannak a rendörségtöl és Neked is el kell menni Apukával és Anyukával". Ágira most is emlékszem. Olyan fehér lett, mint a fal, de Márta azt mondta, hogy biztos azért, mert gyorsan biciklizett a Rimanóczy utcán és az apukája már sokszor mondta, hogy a rendörségre kerül gyorshajtásért.]

Unlike diaries written in many other parts of Europe, in which the escalation of repression against the Jews progressed over a period of years, Éva's diary vividly gives an account of the day-to-day anguish of the sudden and swift attack on the Jews of Hungary, and from the moment she announced that the Germans had taken power in Hungary, the diary recounts an endless series of restrictions, decrees, and events, capturing how in a period of six weeks the confiscation of everything of value, culminated in ghettoization. In the ghetto, what little was left, such as cigarettes and the thirty pengő each person had been allowed to take in, was also confiscated, and finally women's bodies were searched internally. On May 5, Éva's grandmother's and her mother's wedding rings were taken away, as were her grandfather's valise and her red handbag because they were leather. But particularly poignant is Éva's recounting of the confiscation by a ghetto policeman of the gold chain on which she kept the key to her diary:

One of the policemen saw a gold chain on my neck, the one I Got for my birthday, the one holding your key, dear diary. Don't you know yet, the policeman said, that you aren't allowed to keep anything of gold? This isn't private Jewish property anymore. But national property (27-28).

[Az egyik rendör meglátta a nyakamban a kis aranyláncomat, amit a szuiletésnapomra kaptam, és amin a te kulcsodat viselem, kis Naplóm. "Még mindig nem tudják, hogy nem szabad aranytárgyat maguknál tartaniuk? Ez most már nem zsidó magántulajdon többé hanem nemzeti vagyon.]

Before Éva gives up her chain, she puts her diary key on a velvet ribbon and, hiding her trauma behind irony, asks the policeman: "Mister Inspector, am I allowed to take a velvet ribbon into the ghetto?" [Biztos úr, bársony szallagot vihetek a gettóba?]. Éva foretold her death. On May 
Vasvári, Louise O. "Hungarian Women's Holocaust Life Writing in the Context of the Nation's Divided Social Memory, 1944-2014." Hungarian Cultural Studies. e-Journal of the American Hungarian Educators Association, Volume 7 (2014): http://ahea.pitt.edu DOI: 10.5195/ahea.2014.139

30, 1944, two days before her deportation, in the last entry, faced with imminent deportation she says she was rushing to see Mariska Szabó, the family's Christian cook, to whom she entrusted the diary. The last diary entry reads: "I don't want to die because I have hardly lived!" [Én nem akarok meghalni, mert még alig éltem!]. She was deported on June 2, 1944 and killed in Auschwitz on October 17 at age thirteen.

Éva's mother, Ágnes Zsolt, a journalist, was married to the popular novelist Béla Zsolt, who spent a year and a half on the Eastern Front, and who himself wrote Kilenc koffer ['Nine Suitcases'] in 1947, a non-fiction Holocaust novel, in which he described not only his jobs in the labor service as variously aknakutató, sírásó, kocsis, erdőirtó, and bunkerépitö ['mine detector, gravedigger, coachman, forester, bunker builder'], but also, from his perspective, the ghetto life in Nagyvárad, as does Éva (on which cf. also Tsur 2005, Löwy 2010). Béla and Ágnes Zsolt managed to get out of Nagyvárad and eventually to Switzerland with the Kasztner transport but Ági, as she is referred to throughout her daughter's diary, unable to take both her husband and daughter, left the latter behind. She published the diary in 1947 under her own name, with the title Éva lányom ['My Daughter Éva']. The cover of the volume shows a young girl with braids, full of life, smiling into the camera, with a Jewish star superimposed on her photo. ${ }^{5}$ It contains two poignant appended letters, one from Mariska, the family cook who returned the diary to Ági after the war, and another from the governess Justi, who questions who holds responsibility for them not having been able to save Éva. In 1951, four years after the publication of Éva's diary, Ági, full of guilt, committed suicide. Ever since the book's initial appearance it has been surrounded by controversy about of the authenticity of whether Ági rewrote parts in her daughter's voice and suppressed other parts, which is unlikely given that Éva's criticism of her mother in the diary is left intact.

Lilla Ecséri (1928-1986), from a middle class family in Budapest, started writing her diary at fifteen and a half on January 1, 1944 and wrote sporadically through February 1945, while her family was almost constantly on the move, often separated. She also spent a period as a female munkaszolgálatos doing agricultural labor, but, amazingly, she was able to keep her diary with her. Her diary is characteristic of what Kunt (2009) shows in his article about the war diaries of eight Hungarian adolescents, that they tried to protect their mental world and their selfconfidence by daily pleasures and by imaging their future as worth living for. In Lilla's case she talks constantly about wanting to become an actress and even writing the great novel of her life in her old age and imagining that suffering is good preparation for her artistry; she goes as far as when two sisters cry about the death of their father she watches how they do it so she can one day do it better on the stage. Lilla recounts little incidents like getting into an argument with her aunt about buying new shoes at such a time (more precisely about reselling a pair of too big size shoes to her cousin so she could buy a smaller one). Throughout her diary Lilla is constantly

\footnotetext{
${ }^{5}$ The original 1947 Hungarian version of Éva's diary was not reprinted until 2011; it also appeared in Hebrew in 1964, in English in 1974 and, translated from the Hebrew to English (Marton 1988), and in German and French in 2013. Excerpts are included in English in several collections, including Holliday (1995), Boas (1996), who himself was born in 1943 in the Westerbork Concentration Camp. For a literary analysis see Kunt (2009), Schwartz (2014), and also the recent discussion around the new Hungarian edition ["Heyman Eva," 2011], which includes additional photos of Éva.
} 
Vasvári, Louise O. "Hungarian Women's Holocaust Life Writing in the Context of the Nation's Divided Social Memory, 1944-2014." Hungarian Cultural Studies. e-Journal of the American Hungarian Educators Association, Volume 7 (2014): http://ahea.pitt.edu DOI: 10.5195/ahea.2014.139

preoccupied about how she is not good looking enough, especially compared to her better looking cousin and how although she is almost sixteen and-later in the diary, after her birthday - over sixteen and she has never had a boyfriend, even though she would love to have one and would like to csókolózni ['kiss, make out']:

About boys: generally a sixteen-year old girl should have a boyfriend [but] I don't have one and have never had one. [here and elsewhere, unless otherwise indicated all translations are mine]

\section{[A fiúkról: általában 16-éves lánynak már kell hogy legyen udvarlója. Nekem} nincs és sohasem volt.]

Lilla's diary, which was first published in 1995 as Napló 1944: egy tizenhat éves kislány naplójának eredeti szövege ['Diary 1944: The Original Text of the Diary of a Sixteen Year Old Girl'] has not been translated into any other language. Excerpts are available at www.holokausztmagyaroszagon.hu.

In a quote from early in her diary on March 24, Lilla describes how the day they had to put on the yellow star transpired, with people arguing about the significance of the German invasion:

Everybody is discussing politics, they are all very upset and yammering. Even the Christians are upset, and those of Jewish origin even more. As to why the Germans occupied us when we are their allies there are many answers, and precisely because of that I'd rather not write anything. Let history decide. Of course that history that after the war will be true, because in school they teach us the history of World War II from the German perspective....Even just a month ago things were better, because we could walk on the street, and go to films and to the theater (11).

[Mindenki politizál, oda van, sír, jajgat. Még a keresztények is odavannak, hát még a zidó származásúak. Hogy miért szálltak meg minket a németek, dacára, hogy szövetségeseik vagyunk, arra rengeteg felelet van, s pont ezért inkább semmit sem írok, a törtenelem majd eldönti. Persze az a történelem, ami majd a háború után igaz is lesz, mert nálunk a suliban is németpártoló iráyban tanítják a II. Világháborút.... Még egy hónappal ezelött is jó volt, mert járhattunk az utcán, moziba, szinházba mehettünk.] 
Vasvári, Louise O. “Hungarian Women's Holocaust Life Writing in the Context of the Nation's Divided Social Memory, 1944-2014." Hungarian Cultural Studies. e-Journal of the American Hungarian Educators Association, Volume 7 (2014): http://ahea.pitt.edu DOI: 10.5195/ahea.2014.139

On October 15, 1944, on the day Ferenc Szálasi took power after Horthy had tried to step out of the war, Lilla writes that she still thinks she'll survive but, if not, she is also ready to die: ${ }^{6}$

I am totally relaxed and I look at everything phlegmatically. I am convinced that we'll get through it all. But if not (which I don't think is likely), well, then, they'll just take me away and kill me.

[Én abszolut nyugodt vagyok, és flegmával nézem az egészet. Meg vagyok gyözödve hogy megússzuk a dolgot. De ha nem (amit nem tartok valószínünek) hát legfeljebb elvisznek és megölnek.]

It may seem surprising to readers that in her entry from August 22 Lilla can write that she feels better in the ghetto than locked up alone at home earlier, but in fact she is not the only teenage girl to prefer the companionship offered by ghetto life, along with its hardships, and not knowing then what we now know about the ultimate fate of the ghettos. For example, thirteen-year old Hungarian Elli Friedman (Bitton-Jackson 1999, Vasvári 2009a), the subtitle of whose memoir is Coming of Age in the Holocaust, writes about how she likes standing in line for the toilet in the ghetto because that is where everyone meets to gossip, and she also recounts her infatuations with boys she meets there. This is how Lilla explains why she enjoys life in the ghetto:

I feel great. It seems the ghetto does me good. I live much better here than I lived at home because there are people to talk to, to get together with, not like at home, where all day I sat in the room and read. There are lots of girls in the house and I'm friends with all of them. I think that they like me and think of me as a good sport. We tell each other jokes (very dirty ones) (12).

[Remekül vagyok. Úgy látszik, jót tesz nekem a gettó. Sokkal jobban élek itt, mint otthon éltem, mert van, akivel beszélgessek, összejöjjek, nem úgy mint otthon, ahol egész nap a szobában ültem és olvastam. Rengeteg lány van a házban, akikkel mind jóban vagyok. Azt hiszem, szeretnek és jópofának tartanak. Vicceket (jó disznókat) mesélünk egymásnak.]

A very sobering contrast to the diaries of Éva Heyman and Lilla Ecséri is provided by a recently published wartime diary of Brigitte Eickle (1928-)(Gröschner at al. 2013), a gentile Berlin teenager who was the same age as Lilla, which sadly illustrates the public indifference by many eyewitnesses to the plight of the Jews. Fifteen-year old Eickle, in training to be a secretary, begins her diary on December 24, 1943, saying that she is writing to practice her stenography and that she will write about alltägliche Begebenheiten ['everyday occurrences'], and, indeed,

${ }^{6}$ I cannot deal here with the briefer diary, but one that she kept from 1941 to 1945, of Éva Weinmann (2004), who was exactly the same age as Lilla and who writes with even more preoccupation about boys and clothing, but it is interesting to compare their two very different reactions to the Oct. 15, 1944 events, where Éva describes her own and everyone else's panic. She survived but died in 1946 and her diary was given to the Lauder Javne Archives in 2004. 
Vasvári, Louise O. "Hungarian Women's Holocaust Life Writing in the Context of the Nation's Divided Social Memory, 1944-2014." Hungarian Cultural Studies. e-Journal of the American Hungarian Educators Association, Volume 7 (2014): http://ahea.pitt.edu DOI: 10.5195/ahea.2014.139

her diary is an account of seeing bad films, first kisses, visits to the dressmaker, and complaints about a terrible permanent wave, interspersed with casual comments like that when she went to the movies she saw that "Jews all over town are being taken, including the tailor across the street." Eickle, still alive today at 86, claimed in interviews that she was busy with her own life and too young to notice anything.

Unlike the previous teenage diarists, Borbála Szabó (1920-1975), born in Budapest, was a woman of twenty-four when she started her diary. She wrote about daily life in the Budapest ghetto for her deported fiancée, whom she was never to see again. She met Lajos Krausz in 1943 after his return from munkaszolgálat in Ukraine. After a few months of courtship, in fall 1944 he was deported and in November she herself was conscripted for a labor battalion in the engine house of the Ferencvárosi Railroad Station. In December she moved voluntarily to the ghetto with her mother and Lajos's parents. She started writing her diary in the form of letters for her fiancé just a few days after September and wrote almost daily until liberation in February 1945. She describes the last days of World War II, which the four of them survived but Lajos, murdered in Bergen Belsen, did not. She writes repeatedly about the process of writing and about her inability to write well enough to record everything, worrying that after the war, when she and Lajos read it together, it will not represent all that happened. She describes the increasing dehumanization process of life in the ghetto, of how, for example, because they are not allowed any stores or activity in the ghetto people become coarser and coarser and would kill for food. She singles out two young men in her group, who have returned from munkaszolgálat, having undergone far more suffering than anyone else there, and yet they extend help to others in the ghetto. Throughout her diary Borbála writes in an "I am a camera" mode and, amazingly, in spite of her fluctuating feelings, she seems to keep faith and hope alive. Borbála's diary was published only in 1982 by her daughter, who had known about her mother's diary since she was ten but only found and read it many years after her mother's death (see excerpts and photos from Szabó's Hungarian text in "Budapesti napló," www.yadvashem.org.). Borbála's niece, Vera Szabó (2009) has published an important excerpt from the diary in English, with an introduction, where she also provides some details of Borbála's postwar life, cogently stating that the diary shows the "interior life of a surprisingly strong and mature young woman." Unfortunately, to date only Hungarian readers who can read the full text are able to get a full sense of the strength and amazing optimism of Borbála's personality and begin to understand the incredible level of escalating terrors through which she had to struggle to survive as well as help both her mother and her fiancé's parents survive.

There are many other diaries, which remain forgotten in archives or in private hands; some have only been recently published, usually privately, and others have simply not come to light, not to mention all those destroyed or discarded once their owners were murdered. ${ }^{7}$ The

${ }^{7}$ On the thousands of destroyed and discarded Holocaust diaries see the mention above of the Warsaw Ghetto Oyneg Shabbos project, where hundreds of people of all ages and both genders kept diaries but where after every liquidation of inhabitants, ghetto diaries, photographs, and other documents would be found strewn on the streets. Specifically for Hungary see examples like that of the Diaries of Ottó Komoly (Vágo1970), who was Chairman of the Hungarian Zionist Organization, Leader of the Rescue Committee, credited with saving thousands of children by creating orphanages, etc., and who was murdered by Arrow Cross on Jan. 1, 1945. His widow and daughter took the diary to Israel. 
Vasvári, Louise O. "Hungarian Women's Holocaust Life Writing in the Context of the Nation's Divided Social Memory, 1944-2014." Hungarian Cultural Studies. e-Journal of the American Hungarian Educators Association, Volume 7 (2014): http://ahea.pitt.edu DOI: 10.5195/ahea.2014.139

most dramatic such find, the diary of Rywka Lipszyc (2014), just published, chronicles through the eyes of a religious fourteen-year-old girl six months, from October 13 to April 12, 1944, in the Lodz Ghetto, four months before the ghetto was liquidated and all remaining survivors were transported to Auschwitz. The diary was recently found in San Francisco and authenticated. Apparently Rywka had taken her diary with her to Auschwitz, where it was probably thrown into the trash and rescued by a member of the Sonderkommando. It was later discovered outside the crematorium by a female Red Army doctor, Zinaida Berezovskya, and brought to light only seven decades later in 2008 by her granddaughter in San Francisco.

Compared to the diary of Borbála Szabó, the writing of Susan Kaszas [sic] (1920-1990), born in Györ, is much shorter, a thirty-page diary-like immediate memoir when liberated in April 1945. Unfortunately it is available only in its 2002 translation into English by her son, Steven Kingsley. ${ }^{8}$ Like Borbála Szabó, she composed her diary in the form of a love letter to her husband, the thoughts of whom gave her strength to survive. ${ }^{9}$ In spite of the brevity of Kaszas' memoir it is valuable for its description of many dreadful events that have also been touched upon in other texts discussed here. Her husband was sent to munkaszolgálat from the Tapolca ghetto and she describes how platoons of forced laborers had to watch their relatives being marched through town to be deported, including a friend of her husband's, who watched with enraged face and clenched fists the deportation of his seven months pregnant wife. Kaszas describes eloquently how it felt to be in such a procession herself:

Forced toward the main station, so many of us that we covered the whole stretch of the [?] street. The line was so long we could not see where it ended. Christian neighbors and families were crying in the windows... Our Hungarian "compatriots" were vile enough to hand over the children and elderly to the Gestapo, even though the Germans only asked for the young and mature [i.e., 'able bodied'] population from the ghetto... In a lot of ways the Hungarians behaved more despicably than the Germans (Kaszas 2002 books.google.hu).

To visualize how very publicly visible to the whole community events like the deportation described here by Kaszas were in Hungary, compare the photographs and analysis in Cole (2011: 85-101) of Jews herded in the middle of the day through main streets towards the railway station in Körmend, Köszeg, and Balatonfüred, accompanied by only a few gendarmes and with

\footnotetext{
${ }^{8}$ Although his mother lived her whole life in Hungary, Kingsley annoyingly chose to Anglicize her name and that of every Hungarian mentioned in the diary and he also dispensed with the accent mark on her last name.

9 Ágnes (Hálasz) Rózsa (1920-?) (1971), who was deported with her parents from Nagyvárad to Puschwitz, then to slave labor in the Siemens factory in Nürnberg, managed to keep a dairy in the form of letters to her husband, Gyula Shapira. With the collaboration of her fellow prisoners, she wrote on wrapping paper and camp announcements and kept the papers in a bag around her neck that she had sewn. Both she and her husband survived but he died soon after liberation.
} 
Vasvári, Louise O. "Hungarian Women's Holocaust Life Writing in the Context of the Nation's Divided Social Memory, 1944-2014." Hungarian Cultural Studies. e-Journal of the American Hungarian Educators Association, Volume 7 (2014): http://ahea.pitt.edu DOI: 10.5195/ahea.2014.139

townspeople looking on. ${ }^{10}$ Kaszas also writes about the furor of the Hungarians to obtain any hidden valuables. So-called midwives searched inside women's bodies and also took away every penny and all documents and photos. Many people were kicked, beaten, and tortured until they gave details of everything they had hidden and then they were thrown into a ditch. Nor does Kaszas spare details on the cruelty of other Jews, such as her mother-in-law, who she claims hated her so much that she would have denounced her for deportation when Kaszas managed to get her name deleted from the list. When Kaszas does end up in Birkenau she says of that experience that there she was emotionally in better shape than when she had been forced to live with her husband's family while he was in munkaszolgálat because she knew that in the camp she was suffering because she was a Jew but she could not endure the psychological torture his family had meted out to her. Although $95 \%$ of both families of the couple perished, Kaszas and her husband survived, only to have their lives be shattered once again when they tried to rebuild their lives by opening a country store, which was later nationalized under Communism.

There remain today many untouched diaries in Hungarian archives that received no scholarly attention until Gergely Kunt (2013) wrote in his Ph.D dissertation about many such diaries, including the adolescent war diaries of Éva Heyman and Lilla Ecséri (see, in this issue, his article, "Ironic Narrative Agency as a Method of Coping with Trauma in the Life Writing of Margit K., a Female Holocaust Survivor”). Like both Szabó and Kaszas, thirty-six year old Margit, from an assimilated family in Buda, wrote as a form of virtual communication in the form of letters to her husband. Margit's work is a combination of diary and immediate memoir, where between March 6 and May 10, 1945, right after liberation, she rewrote her seventy-page diary into a two hundred-page memoir that she dubbed ironically as posthumous napló [posthumous diary]. In the memoir she recasts the tragic events of the diary by creating an ironic narrative persona who invents euphemistic neologisms such as bujdokolok ['I am in hiding' with the verb conjugated to sound like a game], and a whole series of new word creations around csillag ['the yellow star'], such as: a csillag premierje ['the premiere of the star,' i.e., the appearance of laws on wearing the Jewish star], elcsillagodás ['getting all starry,' i.e., the day when all Jews had to start wearing the star], and csillagos szabadidö ['startlit/fantastic free time,' i.e., when Jews were allowed in the street to shop]. Somewhat akin to Imre Kertész in his Fatelessness, Margit K. can write with mock irony even about grotesque events like people being shot into the Danube. Here is a small sample of Margit's style, where as a psychic defense mechanism she follows a list of horrors experienced in 1944 with a joking reference to preparing for possible deportation as if she were going on a társutazás [package holiday] (not rendered in quotes in her text):

\footnotetext{
${ }^{10}$ For another form of visualization of what such a parade of deportees through the main street of towns would have looked and felt like to victims and onlookers alike, see the poignant brief video by Kristof Pajor, "Wesselényi 1944." On the basis of archive photos of Jewish women wearing yellow stars being marched through Wesselényi Street with raised hands, Pajor recreated the scene in the identical location in a moving picture, including women and girls of various races in order to create a bridge in time with the present and to universalize the suffering: http://wesselenyi1944.tumblr.com.
} 
Vasvári, Louise O. "Hungarian Women's Holocaust Life Writing in the Context of the Nation's Divided Social Memory, 1944-2014." Hungarian Cultural Studies. e-Journal of the American Hungarian Educators Association, Volume 7 (2014): http://ahea.pitt.edu DOI: 10.5195/ahea.2014.139

This period was in one word all about anxiety, fear for one's life, hiding one's belongings, liquidation, etc.: it was about then that I cut my hair short, counting on a longish and crowded group trip in a locked railway car.

[Ez a korszak egyszóval a szorongások, halálfélelem, holmidugások likvidáció, stb. jegyében zajlott: körülbelül ekkor vágtam le a hajamat rövidre, számítva egy hosszabb és zsúfolt társutazásra zárt vagonban.]

Although Margit K. rewrites her diary as a memoir immediately after the events, she uses the retrospective format not so much to provide more historical details or to try to reflect on the events, but as an attempt to excise her trauma by ironizing the past. We can see by the example of Margit K., as well as the other Hungarian female diarists I have mentioned, that neither psychosexual development nor artistic creation are inevitably crushed by the Holocaust and that, in fact, producing art in such extreme circumstances can instead serve as a "strategy for psychic, ideological, moral and even physical resistance to annihilation" (Clementi 2013: xiv).

It is worth reiterating that none of the works I have discussed so far have achieved more than minimal readership and that, as in the case of Éva Heyman and Borbála Szabó, if they are known at all or utilized for pedagogical purposes it is not necessarily in Hungarian. The only female diary of World War II that is widely known is that of gentile Christine Arnothy, born in Budapest in 1930, who spent the Russian siege of Budapest with her parents in the basement of their building near the Danube in Buda, along with a dozen other tenants. She kept a daily journal in a school notebook in which she described the positive and negative interactions among the group as they all starved, froze, and suffered from thirst, saw dead humans and horses on the streets, and smelled the odor of death everywhere. The one Jew among them, whose family had been deported, is summarily shot by the Russians right after liberation when he objects to going to do malenkij robot [forced labor]. Christine sewed her journal into her coat when her family escaped to Austria in 1948, and in her later emigration to Paris rewrote it as an autobiography, with addition of details of how they left, and published it in French in 1955 as J'ai quinze ans et je ne veux pas mourir [I am Fifteen and Don't Want to Die]. At its publication the book was heralded by reviewers as the tender juxtaposition of the war's brutalities with youth and it became a worldwide success, was translated to several languages and sold over twenty five million copies. Along with her subsequent Il n'est si facile de vivre ['It's not So Easy to Live'], published in one volume, the first book has sold over three million additional copies (cf. also Vasvári 2012 [and in Hungarian in 2011 in this journal] on the wartime diary of Transylvanian Hungarian Alaine Polcz, who describes the mass rapes by the Russian forces).

\section{Hungarian Women's Cookbooks as Gendered Fragmentary Discourses of 1944}

Karen A. Foss and Sonja K. Foss in their Women Speak: The Eloquence of Women's Lives (1991; see also Bower 1997) discussed the importance of redefining models and theories of communication based on masculine norms that tend to exclude women's experience and sensitivity, and the need to make into subjects of legitimate scholarly investigation artifacts and activities of unknown or marginalized and typically female gendered discourses. Such discourses, in the form of cultural artifacts previously viewed as trivial, include not only letters, diaries, and memoirs, but also numerous other forms of expression, such as quilt making, samplers, needlework, scrapbooks, photos, and cooking; all forms of expression produced by ordinary women relegated to the domestic sphere. The initial efforts to redefine women as 
Vasvári, Louise O. "Hungarian Women's Holocaust Life Writing in the Context of the Nation's Divided Social Memory, 1944-2014." Hungarian Cultural Studies. e-Journal of the American Hungarian Educators Association, Volume 7 (2014): http://ahea.pitt.edu DOI: 10.5195/ahea.2014.139

communicators has been to recover women's texts, a process that still continues, as I have tried to do in the previous section on female adolescents' and young women's Holocaust life writing. Such writing in wartime was very difficult for anyone, but for many women, such as those in concentration camps, it was normally impossible. For them, as many camp memoirs testify, the only method of actively resisting the annihilation of their humanity by the Nazis and to "write their lives" in the face of death was by oral communication with their sorstársak ["fellow inmates,' or, as Rosen (2008) aptly calls them, "sisters in sorrow"], by reciting poetry, telling stories, and recounting events from their past lives. An important component of this female dialogic communication was a form of fantasy cooking through the sharing of recipes, which women called cooking with the mouth (Goldenberg 2003: 169). Women would share reminiscences of food, which gave them emotional sustenance and connected them with their earlier life of family, their religious heritage, and with dead relatives who might be remembered through recipes; some women in camps became teachers to pass on skills and traditions, a sense of self-worth and reaffirmation of community to others. Recipe sharing is an almost prototypical feminine activity to such a degree that, as Marion Kaplan (1990) writes, the League of Jewish Women in Nazi Germany encouraged women to produce cookbooks as a way to maintain a semblance of normal life. Cookbooks and recipes, besides describing foods, are forms of stories that allow for self-representation, telling about family culinary traditions, social class and level of assimilation. They are also records of women's social exchanges and examples of their collective writing even when they appear under a single name. Holocaust cookbooks, then, a previously unrecognized kind of Holocaust literature, can be considered as a form of memoir or perhaps more precisely as a communal partial autobiography, with women's home-centered experiences as an integral part of a gendered history of the history of the Holocaust, which can help to recover the lives of women. As the term cooking with the mouth indicates, most such cookbooks remained as oral exchanges but in rare cases inmates were able to steal some paper and pencil to be able to create concentration camp cookbooks, a tiny number of which have survived, while most, like the Holocaust diaries discussed above, disappeared along with their authors.

I must reserve for a forthcoming study the more detailed discussion of the fascinating trauma discourse of Holocaust cookbooks (Vasvári 2015), but suffice it to say that many of them remain uncatalogued in archives in Yad Vashem and elsewhere. A few have been published but only one to critical success, the cookbook of Minna Pächter, a sixty-seven year old German speaking Czech inmate of Teresienstadt, which features eighty two recipes, including for breast of goose, chocolate torte, and plum strudel. The text is on brittle paper and in faltering handwriting by various hands, often written in broken German. Ironically, Pächter herself died of starvation on Yom Kippur 1944 but her diary, after undergoing a long and tortuous journey of over half a century over several continents, survived to give testimony of her life and suffering and was published in 1996 (Da Silva 1996). 
Vasvári, Louise O. "Hungarian Women's Holocaust Life Writing in the Context of the Nation's Divided Social Memory, 1944-2014." Hungarian Cultural Studies. e-Journal of the American Hungarian Educators Association, Volume 7 (2014): http://ahea.pitt.edu DOI: 10.5195/ahea.2014.139

The first published Hungarian-language Holocaust cookbook appeared last year, Szakácskönyv a túlélélésért (2013), edited by Szilvia Czingel, a folklorist and musicologist who participated between 2001 and 2008 in collecting oral histories from survivors for Centropa. ${ }^{11}$ The original recipe manuscript fell out of the cookbook of Mrs. István Endrei, Hedvig Weiss (1914-2012) in 2007, when she wanted to show the interviewer a recipe for flódni, as an example of the kind of recipes she used to prepare with her mother. Hedvig had lived with her husband for only a few weeks, as he subsequently disappeared in munkaszolgálat. The oral history part of the volume, where Hedvig recounts her life in Budapest near the Nagycsarnok ['the Great/ Market Hall'], provides an eloquent picture of lower-middle class life in Budapest between the two world wars. In the later part of her story, dealing with her wartime experience, Hedvig recounts that when she had to report on November 9, 1944 to the téglagyár ['brick factory'] in Buda, the collection point for deportation, deportees were sent home to come back the next day because there was no transport available, but the concierge of her building went to the police to denounce her as having escaped! Hedwig and four other starving Jewish women arrived in December 1944 in Lichtenwörth, near Wiener Neustadt, to a lager that housed 2,500 women (on Hungarian slave laborers in Austria see Lappin-Eppel 2010). While Lichtenwörth was not a death camp per se, starvation was constant and they were often deprived of food for two and three days at a time, and, like in other camps, when they did get something to eat it was constantly soup of potato skins or marharépa [a kind of turnip used for animal fodder]. While dictating recipes the women would also tell family stories, and Hedvig became the scribe for the cookbook because she had a pencil and paper and because, as she recounts in the oral history, she wrote in very small letters in a tight script:

I just kept on writing with very small letters, so that it would fit on the paper. We had no special consideration for what kind of recipes we wrote down, just what happened to occur to us...

\section{[Én csak írtam, nagyon apró betükkel, hogy elég legyen a papír. Nem volt} szempont, hogy milyen típusu ételeket írunk. Ami éppen eszünkbe jutott...]

Hedvig wrote down 140 recipes but contrary to what she says, there was a particular consideration to which recipes were dictated by the starving women, even if they weren't aware of it at the time. While the collection as a whole represents Central East European gastro-culture, with lots of sour cream, it includes no simple foods like soup of fözelék [vegetable stew] but rather lots of desserts, meat and potatoes, and fatty foods in general. Although there are some

${ }^{11}$ Editor Czingler had worked for Centropa's Holocaust survivor archive. Centropa investigates Central and Eastern-European Jewish life from the turn of the previous century to today. Part of its aim is to guard tradition. They did life interviews in fifteen countries and have an online archive of 1500 life interviews and 2200 photos and other documents. Centropa Magyarország (www.centropa.hu) did 220 interviews in Hungarian, with close to 5000 photos and documents digitalized. Czingel reports that since her publication of Hedvig's cookbook, others have brought her recipes. 
Vasvári, Louise O. "Hungarian Women's Holocaust Life Writing in the Context of the Nation's Divided Social Memory, 1944-2014." Hungarian Cultural Studies. e-Journal of the American Hungarian Educators Association, Volume 7 (2014): http://ahea.pitt.edu DOI: 10.5195/ahea.2014.139

specifically Jewish dishes, there is nothing kosher about the collection as a whole. By way of illustration of the recipes in the collection, I have chosen the one for vanilla crescents because my own Christian mother, who could not follow written recipes, would make it every Christmas, and would make me read the recipe to her:

Vanilla crescents: work together $15 \mathrm{dkg}$ flour with $10 \mathrm{dkg}$ butter, $5 \mathrm{dkg}$ sugar and $5 \mathrm{dkg}$ ground almonds into a noodle shape and form crescent shapes and bake them to a light color and strew with vanilla sugar.

[Vaníliás kifli: 15 dkg lisztet, 10 dkg vajjal, 5 dkg vaníliás cukorral, 5 dkg darált mandulával összedolgozni, (nudlibol) kifliformát készíteni, világosra sütni és vaníliás cukorral hinteni.]

The five women were liberated on April 2, 1945, and all five survived although two got typhus on the way and arrived two weeks later; and they all made the whole way home walking. As the scribe it fell to Hedvig to hold the recipe collection as a keepsake for over sixty years until it happened to fall out of her cookbook. She passed away in 2011 at the age of ninety-eight. When we read cookbooks like that of Hedvig, we see what sharing recipes meant for survival for women in the Holocaust. It then becomes sad to read the recent stridently sarcastic commentary by the philosopher and public intellectual Gáspár Miklós Tamás (2014) trivializing the Jewish memento receptek ['memorial recipes'] prepared by a well-known female chef at the June 25 , 2014 "Nights of the Starred Houses" commemoration of 1944. Tamás ridicules the event in the following terms:

Holocaust gastronomy? Gourmet genocide? Gestapo fine dining? Gourmet kapos? Gault-Millau [famous French restaurant guide] slave labor? Poor hapless, deranged Hungary!

[Holokauszt-gasztronómia? Gourmet genocidium? Gestapo fine dining? Ínyenc kápók? Gault-Millau munkaszolgálat? Szegény szerencsétlen, tébolyodott Magyarország!]

Tamás seems to be saying that Hungary is deranged to turn the genocide into a food fair of food kitsch nostalgia, which distorts the memory of utter atrocity, but I would counter that when we recuperate the history of how important "cooking with the mouth" was for these women we realize that we can honor their memory through memorializing their food ways.

All the women I have discussed so far wrote in the midst of war in 1944, some into early 1945. Sari (Slovak) Biró (1904-1995), who on her marriage in 1925 got as a present a notebook for writing up recipes, can serve as a transition to the final group of women I will discuss briefly, namely, survivors and daughters of survivors who wrote retrospective memoirs many years later. Sari, who lived a well-to-do upper middle class life in Budapest, kept adding to her recipe collection and became a famous cook in her circle. She was so attached to her recipe book, which also served as a diary, that she took it to the ghetto with her and after the war to prison, where she was locked up for two months for trying to cross the border. When word got around the prison about her cooking skills Sari was asked to cook for the staff and the prisoners. In 1957 she left behind her husband and went to America to join her daughters who had fled in 
Vasvári, Louise O. "Hungarian Women's Holocaust Life Writing in the Context of the Nation's Divided Social Memory, 1944-2014." Hungarian Cultural Studies. e-Journal of the American Hungarian Educators Association, Volume 7 (2014): http://ahea.pitt.edu DOI: 10.5195/ahea.2014.139

1948. At first she took care of a child, then started baking and catering, and eventually, laboriously rewriting all her recipes into American measurements, wrote Flavors of Hungary: Recipes and Memoirs (1973). The cookbook became a bestseller and was subsequently reprinted several times through 1992. However, in the cookbook Biró does not divulge her background and we learn additional details of her life and Holocaust experiences only because her daughter, Agnes Biro Rothblatt, published a memoir of her own in 2010, where she writes touchingly of her mother's attachment to her recipe notebook throughout the vicissitudes of her life:

Sárika took her cookbook along [to the ghetto]. It became her diary and was her journal. The changes in lifestyle, cooking method, and family events were all in there. Memories of her mother, Mama, her life as an aspiring socialite, her attempts as a creative cook, caring mother, and, later, survivor in a war-torn city, were recorded on those pages. The book's cover was no longer shiny but worn and faded.... She covered the book with a clean newspaper and tucked it into her air raid shelter pack. Maybe it would be useful after the war is over, she thought, or her two daughters might read it when the world normalized again (6).

\section{Cultural Memory in the Present: Hungarian Women's Retrospective Memories/Memoirs of 1944}

The broad term life writing, which includes the diaries, immediate memoirs, and recipe books I have discussed above, also underlines the continuity of life and hence of survivors' stories after the war, the subject of my last section. It can be survivors who write their own retrospective life narratives, but often the process becomes a two-voiced life writing between survivors and the next generation. Bella Brodzki and Celeste Schenk (1988) have called such memoirs the intergenerational and intercultural transmission of imperiled narratives. The family functions as a space of transmission and remembrance of inherited catastrophic histories that might be generationally translated from orality to literacy, that is, whereby survivors tell and retell stories to their children, but it is only the latter who are able to write them down. In other cases it is rather the impact of untold stories silently passed on by survivors, who literally cannot bear the pain of telling that which falls outside the normal limit of what is "tellable," and which spills over into the next generation through objects, behaviors and affects passed down within the family and culture at large (Levine 2006, Vasvári 2009a,b). It has been suggested that daughters of trauma survivors may be more vulnerable to trans-generational transmission of trauma and unconsciously become carriers of trauma that parents reject or suppress due the more permeable ego-boundaries in women, especially in mother-daughter relationships, which may lead women to taking their mother's experience as their own by way of projective identification (Hirsch 1989, 2002; Vogel 1994; Malin 2000; Giorgio 2002).

The body of autobiographical works by children of Holocaust survivors, or postmemoirs, which has become astonishingly large and much more of it written by women than men, will soon provide the only living connection to the memory of the Holocaust as direct survivors will soon disappear (Clementi 2013: 203-205). An eloquent Hungarian example of such twogenerational Holocaust life writing is the recently published postmemory anthology, Lányok és 
Vasvári, Louise O. “Hungarian Women's Holocaust Life Writing in the Context of the Nation's Divided Social Memory, 1944-2014." Hungarian Cultural Studies. e-Journal of the American Hungarian Educators Association, Volume 7 (2014): http://ahea.pitt.edu DOI: 10.5195/ahea.2014.139

anyák. Elmeséletlen történetek ['Mothers and Daughters: Untold Stories'] (Pécsi 2013; reviews by Langh 2013, Huszár 2014). ${ }^{12}$ In this collection thirty five Hungarian women, some themselves child survivors, others born to mother survivors, write Holocaust narratives in which it becomes impossible to separate the autobiography of the daughters from the biography of their mothers; that is, their mothers' lives become the intersubject in the daughters' autobiographies, underscoring the risks of intergenerational transmission, where traumatic memory can be transmitted (or silenced) to be repeated and reenacted, rather than to be worked through. Contributors to the collection include Hungarians from Toronto, Paris, Sydney, Jerusalem, etc., but the majority have lived their lives in postwar Hungary. The authors "restory and restore" their aged or dead mothers, whose stories were never told, or never fully told, or sometimes totally silenced (on the term "restory" see Burstein 2004). In addition, in some of the narratives the daughters incorporate into their retrospective post-war narrative wartime texts written by their mothers, such as diaries and letters. The collection shows multiple pictures of Jewish life from the most harrowing stories, such as Anna Nagy Lengyel's recounting of her quick-witted mother's amazing sangfroid in saving them and others from being shot into the Danube, to scenes of everyday postwar life between survivor mothers and their daughters that challenge the often prevalent idealization of the Jewish mother-daughter relationships. One survivor recounts that she herself was ashamed to speak of what happened to her:

At the beginning I was ashamed to speak, ashamed that it could have happened to me, that I didn't die instead. I was ashamed in the name of humanity, that it could look on (cited in Langh 2013).

[Eleinte szégyelltem beszélni, szégyelltem, hogy megeshetett velem, hogy nem haltam meg inkább. Szégyelltem az emberiség nevében, hogy képes volt végignénzni].

In contrast, another, Ágnes Rápai, the daughter of a survivor who had consistently embroidered stories about the family's past in order to hide their Jewish origins, sharply calls her mother to account posthumously:

Because you only managed to lie until I was fifteen, when something snapped in you and you were forced to tell me de truth. Oh, thank you very much, who the hell needed you explaining yourself. That it had after all not happened this way but that way, that I should forget what you had lied earlier about your family. That your relatives didn't die in the bombardments after all but in Auschwitz (Pécsi 2013: 131).

\footnotetext{
${ }^{12}$ See also Pécsi (2007), to which this collection is a continuation. An even more recent collection of three generational recollections is Laszló (2014), which reached me too late to be considered in this overview. I cannot discuss here but do want at least to mention the Facebook group Családom és a holokauszt ['My Family and the Holocaust'], which emerged in this anniversary year of 2014, with people beginning to share their photos and memories of the war and thereby creating an online memory community.
} 
Vasvári, Louise O. "Hungarian Women's Holocaust Life Writing in the Context of the Nation's Divided Social Memory, 1944-2014." Hungarian Cultural Studies. e-Journal of the American Hungarian Educators Association, Volume 7 (2014): http://ahea.pitt.edu DOI: 10.5195/ahea.2014.139

[Mert csak tizenöt éves koromig voltál képes hazudni nekem, de akkor elszakadt benned valami, és kénytelen voltál elmondani az igazságot. Na, köszönöm szépen, a francnak se volt szüiksége a magyarázkodásra. Hogy nem is így volt, hanem úgy volt, hogy amit elötte hazudtál a családodról, azt felejtsem el. Hogy nem is bombázásban haltak meg a rokonaid hanem Auschwitzban.]

The foregoing quotes illustrate what Anna Földes (2014), a survivor born in 1930, wrote recently about the post-1944 silence concerning the Holocaust, that it had been an ongoing silent conspiracy in which many survivors themselves willingly colluded: "the collective amnesia was a common responsibility, and we didn't even do it on command [but rather] out of inner conviction" [a kollektiv amnézia közös vállalás volt, és még nem is parancsra tettük... [hanem] belsö meggyözödés[böl]]. Földes adds that at the same time there were those after 1945 whom "the suffering made into writers" [a szenvedés csinált írót] . In spite of the existence of a substantial body of such life writing about the Holocaust that has emerged during and immediately after 1944 and until today, Gábor Gyányi (quoted in Földes 2014) points out that collective memory today remains incomplete and fragmented because no common historical consciousness has emerged from those personal life writings. He adds, in relation to the issue of the nation's emlékezetpolitika ['politics of memory'] discussed in the opening of this study that:

The creation of any kind of collective memory is hardly imaginable without individual remembrance; however, official or public memory can exist very well without real or latent collective memory (www.es.hu).

[A személyes visszaemlékezés nélkül aligha képzelhetö el bármiféle kollektív emlékezet létrejötte, a hivatalos, vagy közemlékezet (public memory) viszont a ténylegesen vagy latens létezö kollektiv emlékezettöl is jól meglehet.]

The question remains of what is at stake for the state and for the people in remembering and how such a troubled history can be memorialized and commemorated, as Urvashi Butalia (2000: 286) puts it in relation to the very different historical calamity of the partition of India: "what can you do to mark such a history as anything other than a history of shame?... such histories are not easily memorialized." Certainly the Holocaust history of any one country cannot be written in isolation since all are interrelated and the Nazi plan was also European-wide. For this reason the "The Research Network in Search of Transcultural Memory in Europe," financed by COST/EU, which aims to study how memories of the troubled twentieth century are transmitted and received across Europe, explores the tension between attempts to create a common European memory, or a unitary memory ethics, on one hand, and numerous memory conflicts stemming from Europe's fragmentation into countless memory communities on the other. Christine Kleiser (2009) discusses various current endeavors to create a specific European culture of memory based on the democratic principles of peaceful coexistence and mutual recognition of differing cultural memories. She proposes that such a common understanding cannot be based only on the diffuse meanings of "historical objectivity" but also must contain a political and ethical dimension with the aim of achieving a common coming to terms with all forms of totalitarian past, in order to avoid any future forms of genocide. 
Vasvári, Louise O. "Hungarian Women's Holocaust Life Writing in the Context of the Nation's Divided Social Memory, 1944-2014." Hungarian Cultural Studies. e-Journal of the American Hungarian Educators Association, Volume 7 (2014): http://ahea.pitt.edu DOI: 10.5195/ahea.2014.139

\section{Coda}

To conclude I want to quote a relevant verse from Julia Bauer (1923-2000), whose five hundred and sixty page És mégis ['And Still'] (2012), could have been included in this study since it is part diary, part deep interview conducted with her in old age (Várnai 2013). Born in Somogyszil, a village like so many others, she was deported at nineteen, taken on Whit Sunday, 1944 to a collection ghetto in Kaposvár and from there on July 4 to Auschwitz, where, as well as in munitions factories in Allendorf and Melsung, she managed to write a diary in bits, hiding the paper in her shoe. Because she spent months in a postwar camp it was only in October 1945 that she was on her way back to Budapest on a train. She feared what would happen when she got home if nobody was there and in fact she found on her return that her whole family perished. On the train home this is what she wrote, as a way to reconcile her Jewish identity with her belonging to and longing for her homeland:

Home, yes, home, where no matter how cruelly they persecuted me, with every drop of my blood I long to return. My beloved homeland, it is here that I breathe, Only here can I live. My beloved homeland, What have you done?

You collaborated with the murder (quoted in Várnai 2014).

[Haza, igen haza honnan ha

bármilyen csúnyán is elüldöztek, minden csepp véremmel visszavágyom. édes hazám, itt lélegzek, csak itt élek. szülőhazám, jaj, mit tettél, a gyilkosokkal szövetkeztél.]

\section{Works Cited}

\section{Primary Sources}

Arnothy, Christine. 1955. J'ai quinze ans et je ne veux pas mourir. [I am Fifteen and I Don't Want to Die]. Paris: Fayard.

Bauer, Julia. 2012. És mégis ['And Still']. Budapest: Noran Libro Kiadó.

Biro, Charlotte Slovak. 1973. Flavors of Hungary: Recipes and Memoirs. New York: 101 Production.

Bitton-Jackson, Livia. 1999. Elli: Coming of Age in the Holocaust. New York: Simon and Schuster.

Boas, Jacob, ed. 1996. We Are Witnesses: Five Diaries of Teenagers Who Died in the Holocaust. New York: Scholastic.

Czingel, Szilvia, ed. 2013. Szakácskönv a túlélésért ['Cookbook for Survival']. Lichtewörth, 1944-1945. Prologue by Pál Zavada. Budapest: Centropa.

Da Silva, Cara, ed. 1996. In Memory's Kitchen: A Legacy of the Women of Terezin. Trans. Bianca Steiner Brown. Northvale NJ: Jason Aronson. 
Vasvári, Louise O. "Hungarian Women's Holocaust Life Writing in the Context of the Nation's Divided Social Memory, 1944-2014." Hungarian Cultural Studies. e-Journal of the American Hungarian Educators Association, Volume 7 (2014): http://ahea.pitt.edu DOI: 10.5195/ahea.2014.139

Ecséri Lilla. 1995. Napló 1944: Egy tizenhat éves kislány naplójának eredeti szövege [Diary 1944: The Original Text of the Diary of a Sixteen-Year Old Girl]. Budapest: T-Twins Kiadó.

Fuchs, Marta. 2012. Legacy of Rescue: A Daughter's Tribute. New York: Csaladnak [sic] Press, Sold by Barnes and Noble.

Gröschner, Annett, Barbara Felsman and Groscha Meyer, eds. 2013. Backfisch im Bombenkrieg. Das Tagebuch der Gitti E. Notizen in Steno 1943-1945 [A Teenager in the Bombing: the Diary of Gitti E. Notizen in Shorthand]. Berlin: Matthes and Seitz.

Holliday, Laurel. 1996. Children in the Holocaust and World War II: Their Secret Diaries. New York: Simon and Schuster.

Horváth Zsolt K. 2014. "Egy munkaszolgálatos fényképe" ["The Photo of a Labor Draftee"]. Beszélő May 24 www.beszélö.c3.hu

Kaszas, Susan. 2002. From Love to Triumph: The Holocaust Diary of Mrs. Susan Kaszas. Ridgewood, NJ: AIL Media [retitled reedition of A Mother's Shoah, 1998].

Lappin-Eppel, Eleonore. 2010. Ungarische-jüdische Zwangsarbeiter und Zwangsarbeiterinnen in Österreich 1944 ['Hungarian-Jewish Slave Laborers and Female Slave Laborers in Austria 1944']. Arbeitseinatz_Todesmärsche-Folgen. Wien. Lit Verlag.

László, Klári, ed. 2014. Lerakott kövek. Holokauszt túlélők, gyerekek, unokák ['Putting Stones [on Graves]: Holocaust Survivors, Children, Grandchildren']. Budapest: Oriold és Társai.

Lipszyc, Rywka. 2014. The Diary of Rywka Lipszyc. San Francisco: JFHS Holocaust Center.

Löwy, Daniel. 2010. "A soa nagyváradi emlékeiről ['About the Memories of the Shoah in Nagyvárad']" Várad 8 www.varad.ro

Marton, Judah, ed. 1988. The Diary of Eva Heyman. Translated from Hebrew into English. New York: Shapolsky Publishers.

Ozsváth, Zsuzsanna. 2010. When the Danube Ran Red. Syracuse: Syracuse UP.

Pécsi, Katalin, ed. 2007. Sós kávé. Elmeséletlen női történetek [Salty Coffee. Untold Women’s Stories]. Budapest: Novella Kiadó [trans. of four stoires by Thomas Cooper. 2014. Hungarian Quarterly 54.269: 74-81.

— 2013. Lányok és anyák. Elmeséletlen nöi történetek II [Mothers and Daughters. Untold Women's Stories II]. Budapest: Novella Kiadó.

Remnick, David. 2014. “Aflame.” The New Yorker August 14 www.newyorker.com

Rothblatt, Agnes Biro. 2010. A Journey from the Chain Bridge to The Golden Gate. Amherst: SmallBatch Books.

Rózsa, Ágnes. 1971. Jövőlesők. Nürnbergi lágernapló 1944-45 ['Lying in Wait for the Future. Camp Diary from Nürnberg 1944-45']. Bucharest: Kriterion.

Schwarcz, Sándor. 2005. A halál árnyékának völgyében [In the Valley of the Shadow of Death]. Budapest: Oliver Games International.

Szabó, Borbála and Judit Elek. 1983. Budapesti napló (1944 november-1945 január)[Budapest Diary (November 1944-January 1945]. Tények és tanuk [Facts and Witnesses]. Budapest: Magvetö.

Szabo, Vera. 2009. "Borbála Szabó. Letters from Budapest [Budapest Napló].” Bridges: A Jewish Feminist Journal 14.2: 15-20.

Szabolcs, Szita, ed. 1998. Bács Pál visszaemlékezése az 1944-1945 évi kényszermunkára és a mauthauseni deportálásra ['Paul Bács's Recollections of the 1944-45 Slave Labor and the Deportation to Mathausen']. Budapest: Magyar Ellenállók és Antifasiszták Szövetsége. 
Vasvári, Louise O. "Hungarian Women's Holocaust Life Writing in the Context of the Nation's Divided Social Memory, 1944-2014." Hungarian Cultural Studies. e-Journal of the American Hungarian Educators Association, Volume 7 (2014): http://ahea.pitt.edu DOI: 10.5195/ahea.2014.139

Szele, Anna and György Szele, eds. 2004 Kényszermunka, eröltetett menet, tömeghalál. Túlélö bori munkaszolgálatosok visszaemlékezései 1943/4 'Forced Labor, Death March, Mass Death, The Recollections of Labor Bataillion Survivors of Bor , 1943'4'] . Budapest: Makkabi Kiadó.

Tsur, Reuven. 2005. Menekülés a gettóbol. Egy nagyváradi család története ['Escape from the Ghetto. The Story of a Family from Nagyvárad']. Budapest: Norán Kiadó.

Vágó, Béla. 1970. "Budapest Jewry in the Summer of 1944: Otto Komoly’s Diaries." Yad Vashem Studies 8: 81-105

Zsolt, Ágnes. 1948. Éva lányom. A 13 éves Éva harcolt életéért a Harmadik Birodalom hóhéraival de a német vadállat legyözte Évát [My Daughter Eva. The Thirteen-Year Old Eva Fought for her Life Against the Executioners of the Third Reich But She Was Defeated By the German Beast]. Budapest: Új Idők Irodalmi Intézet.

\section{Secondary Sources}

Braham, Randolph. 1981. The Politics of Genocide: The Holocaust in Hungary I. New York: Columbia UP. . 2004a. "Hungary and the Holocaust: The Nationalist Drive to Whitewash the Past." The Treatment of the Holocaust in Hungary and Romania During the Post-Communist Era. Ed. id. New York: Rosenthal Institute for Holocaust Studies, CUNY: 1-41. . 2004b. "Rescue Operations on Hungary: Myths and Realities. East European Quarterly 38.2:173-124.

Brodzki, Bella and Celeste Schenk, eds. 1988. Life/Lines: Theorizing Women's Autobiography. Ithaca: Cornell UP.

Brooks, David. 2014. “Going Home Again.” New York Times, March 20. www.nytimes.com

Burstein, Janet. 2004. "Restorying Jewish Mothers." Jewish-American and Holocaust Literature: Representation in the Modern World. Ed. Alan L. Berger and Gloria L. Cronin. Albany: SUNY P: 235-242.

Butalia, Urvashi. 2000. The Other Side of Silence: Voices from the Partition of India. Bloomington: Duke UP.

Clementi, Federica. 2013. Holocaust Mothers and Daughters: Family, History, and Trauma. Waltham: Brandeis UP.

Cole, Tim. 2001. "Hungary, The Holocaust and Hungarians: Remembering Whose History." Hungary and the Holocaust. Confrontations with the Past. Symposium Proceedings. Foreword, Paul A. Shapiro and Robert M. Ehrenreich . Washington DC: United States Holocaust Memorial Museum, Center for Advanced Holocaust Studies: 3-21. . 2002. "Review Article: Scales of Memory. Layer of Memory: Recent Works on Memories of the Second World War and the Holocaust." Journal of Contemporary History 37.1: 129-138.

- 2003. Holocaust City: The Making of a Jewish Ghetto. London: Routledge, Chapman and Hall. . 2006. "A Gendered Holocaust? The Experiences of "Jewish" Men and Women in Hungary, 1944.” The Holocaust in Hungary Sixty Years Later. Eds. Randolph L. Braham and Brewster S. Chamberlin. New York: Rosenthal Institute for Holocaust Studies, CUNY, Distributed by Columbia UP: 43-61. 
Vasvári, Louise O. "Hungarian Women's Holocaust Life Writing in the Context of the Nation's Divided Social Memory, 1944-2014." Hungarian Cultural Studies. e-Journal of the American Hungarian Educators Association, Volume 7 (2014): http://ahea.pitt.edu DOI: 10.5195/ahea.2014.139

. 2011. Traces of the Holocaust. Journeying in and out of the Ghetto. London: Continuum.

Czenki, Dorka. 2014. “György Péter a Szabadságtéri szoborról ['Peter György on the Freedom Square Memorial'].” Magyar Narancs Julius 22 http://magyarnarancs.hu/kultura/gyorgypeter-a-szabadsag-teri-szoborrol-91023.

Dömötör, Ági. 2014. "Van-e itt gerinc? Interjú a Holokauszt Emlékközpont igazgatójával” ['Is There any Backbone Here? Interview with the Director of the Holocaust Memorial Center']Origo 2013-05-15 www.origo.hu.

Egan, Thomas. 2014. "Lost in the Past." New York Times, May 22 www.nytimes.com

Földes, Anna. 2014. "Személyes emlékezés [Personal Remembrance].” Élet és Irodalom 58.8, Aprilis 28 www.es.hu

Foss, Karen A. and Sonja K. Foss. 1991. Women Speak: The Eloquence of Women's Lives. Prospect Heights NJ: Waveland P.

Giorgio, Adalgisa. 2002. Writing Mothers and Daughters. Renegotiating the Mother in Western European Narratives by Women. New York: Berghan.

Girard, René.1963. Le journal intime ['Intimate Journal']. Paris: Presses Universitaires de France.

Goldenberg, Myra. 2003. "Food Talk: Gendered Responses to Hunger in the Concentration Camps." Experience and Expression. Women, Nazis and the Holocaust. Eds. Lizabeth R. Baer and Myrna Goldberg. Detroit: Wayne State UP: 161-180.

Hanebrink, Paul. 2013. "The Memory of the Holocaust in Postcommunist Hungary. Part I: The Politics of Holocaust Memory." Bringing the Dark Past to Light: The Reception of the Holocaust in Postcommunist Europe. Eds. John-Paul Himka and Joanna Beata Michlic. Lincoln: U of Nebraska P: 261-291.

"Heyman Éva naplója ujra megjelent magyarul"['Éva Heyman's Diary Was Republished in Hungarian']. Szombat 2011-04-27 www.szombat.org

Hilberg, Raul.1985. The Destruction of European Jews. New York: Holmes and Meier.

Hirsch, Marianne. 1989. The Mother and Daughter Plot. Narrative, Psychoanalysis and Feminism. Bloomington: Indiana UP. . 2002. "Marked by Memory: Feminist Reflections on Trauma." Extremities: Trauma, Testimony and Community. Eds. Nancy K. Miller and Jason Daniel Dougaw. Chicago: U of Illinois P: 71-91.

Huff, Cynthia. 1989. "'The Profoundly Female, and Feminist Genre:' The Diary as Feminist Practice." Women's Studies Quarterly 17.3/4: 6-14.

Huszár, Ágnes. 2014. “A női hallgatás megtörése ['The Break in Women’s Silence'].” Buksz 26.2: 71-73.

Judt, Tony. 2000. "The Past is Another Country: Myth and Memory in Postwar Europe.” The Politics of Retribution: World War II and Its Aftermath. Eds. István Deák, Jan T. Gross, and Tony Judt. Princeton: Princeton UP: 293-323.

Kaplan, Marion. 1990. "Jewish Women in Nazi Germany: Daily Life, Daily Struggles. 19331939." Feminist Studies 16: 579-606.

Karsai, László (n.d.) "Photographs Documenting the Holocaust in Hungary" (www.holocausthistory.org).

Karsai, László and Szabolcs Szita, 1994. eds. The Holocaust in Hungary. Sopron: Hillebrand Nyomda. 
Vasvári, Louise O. "Hungarian Women's Holocaust Life Writing in the Context of the Nation's Divided Social Memory, 1944-2014." Hungarian Cultural Studies. e-Journal of the American Hungarian Educators Association, Volume 7 (2014): http://ahea.pitt.edu DOI: 10.5195/ahea.2014.139

Kassow, Samuel D. 2007. Who Will Write Our History? Emanuel Ringelblum, the Warsaw Ghetto, and the Oyneg Shabbos Archive. Bloomington: Indiana UP.

Kiss, Csilla. 2014. "Historical Memory in Post Cold War Europe." The European Legacy 19.4: 419-432.

Kleiser, Christine. 2009. "Avishai Margalit's Idea of Ethics of Memory and Its Relevance for a Pluralistic Europe." Institut für die Wissenschaft des Menschen, Junior Fellowship Conference 25 www.iwn.at

Kunt, Gergely. 2009. "Gyereknaplók a második világháborúból” ['Children’s Diaries from the Second World War']. Aetas 24.2: 44-68.

—. 2013. A kultuszteremtés társadalomtörténete. Szocializáció, elöitéletek, politikai propaganda kamasznaplók tükrében (1938-1956) ['The Social History of the Creation of a Cult. Socialization, Prejudices, Political Propaganda in the Light of Adolescent Diaries (1938-1959). PhD Dissertation, ELTE, Budapest.

Laczó, Ferenc. 2013. Review of Timothy Cole. Traces of the Holocaust: In and Out of the Ghetto. Zeitschrift für Ostmitteleuropa-Forschung 62.4: 684-685 www.herder-institut.de

Laczó, Ferenc. 2014. "German Occupation or Hungarian Responsibility? A Debate on the $19^{\text {th }}$ of March, 1944." Forum Geschichtskulturen, Hungary April 23. www.imre-kerteszkolleg.uni. Accessed Aug. 18, 2014.

Langer, Lawrence L. 1991. Holocaust Testimonies: The Ruins of Memory. New Haven: Yale UP. Lángh, Julia. 2013. "Kaddish az anyákért ['Kaddish for Mothers'].” Élet és Irodalom 57.25, June 21.

Levine, Michael G. 2006. The Belated Witness: Literature and the Question of Holocaust Survival. Stanford: Stanford UP.

Lüdtke, Alf, ed. 1989. Alltagsgeschichte: Zur Rekonstruktion historischer Erfahrungen und Lebensweisen ['Everyday History: Towards the Reconstruction of Historical Experiences and Lifeways'] . Frankfurt: Campus Verlag.

Malin, Jo. 2000. The Voice of the Mother: Embedded Maternal Narratives in Twentieth-Century Women's Autobiography. Carbondale: Southern Illinois UP.

Mink, Georges and Laure Neumayer, eds. 2013. History, Memory and Politics in Central and Eastern Europe: Memory Games. Basingstoke: Palgrave MacMillan.

Orbán, Viktor. 2014. "Mélyen tisztelt Dávid Katalin Profeszor asszony ['Deeply Honored Madam Professor, Katalin David'].” www.origo.hu.

Patterson, David. 2004. "Through the Eyes of Those Who Were There." Holocaust and Genocide Studies 18.2: 274-290.

Rényi, Dániel. 2011. "Egy dicső nemzetkép érdekében-Randolph L. Braham a holokausztkutató." ['In the Interest of an Honorable National Image-Randolph L. Braham the Holocaust Scholar'] Magyar Narancs Nov. 10 www.magyarnarancs.hu

Rosen, Ilana. 2008. Sister in Sorrow. Life Histories of Female Holocaust Survivors from Hungary. Detroit: Wayne State Press. . 2012. "'Soldiers or Slaves.' Narratives of Survivors of the Hungarian Army's 'Labor Service' in World War II and the Holocaust." Dapim - Studies on the Shoah 26: 95-123.

Schwarz, Daniel R. 1999. Imagining the Holocaust. New York: St. Martin's P.

Schwartz, Agatha. 2014. "Eva Heyman, The Hungarian Anne Frank: Writing Against Persecution and Trauma." Hungarian Studies Review 42 [forthcoming].

Stewart, Victoria. "Holocaust Diaries: Writing from the Abyss" Forum of Modern Language Studies 41.4 (2005): 418-426. 
Vasvári, Louise O. "Hungarian Women's Holocaust Life Writing in the Context of the Nation's Divided Social

Memory, 1944-2014." Hungarian Cultural Studies. e-Journal of the American Hungarian Educators Association,

Volume 7 (2014): http://ahea.pitt.edu DOI: 10.5195/ahea.2014.139

Tamás, Gáspár Miklós. 2014. "Csillagos házak.” www.hvg.hu June 23.

Ungváry, Kristian. 2013. A Horthy-rendszer mérlege ['The Balance of the Horthy Regime']. Budapest: Jelenkor.

Vági, Zoltán, László Csősz, and Gábor Kádár, 2013. The Holocaust in Hungary: Evolution of a Genocide. New York: US Holocaust Memorial Museum.

Várnai, Pál. 2013. "Szülőházam jaj mit tettél....['My Homeland, Oh, What Did You Do?']” Szombat February 13: 31.

Vasvári, Louise O. 2006. "Women's Holocaust Memories/Memoirs: Trauma, Testimony and the Gendered Imagination.” Jewish Studies at Central European University 5. Eds. András Kovács and Michael I. Miller. Budapest: CEU, 141-54. . 2009a. "Emigrée Central-European Jewish Women's Holocaust Writing." Comparative Central European Holocaust Studies. Eds. Louise O. Vasvári and Steven Tötösy. Purdue UP and CLCWeb 11.1(2009) (http://docs.lib.purdue.edu/clcweb/vol11/iss1/7 . Accessed Aug. 18, 2014. . 2009b. "Introduction to and Bibliography of Central European Women's Holocaust Life Writing in English." Comparative Central European Holocaust Studies. Eds. Louise O Vasvári and Steven Tötösy. Purdue UP and CLCWeb 11.1(2009) http://docs.lib.purdue.edu/clcweb/vol11/issue1/10 . Accessed Aug. 18, 2014.

- 2011. "The Fragmented (Cultural) Body in Polcz's Asszony a fronton (A Woman on the Front)." Comparative Hungarian Cultural Studies. Eds. Steven Totosy and Louise O. Vasvári. West Lafayette: Purdue UP: 347-370; Hungarian translation: . "A töredékes (kultúrális) test írása Polcz Alaine Asszony a fronton című művében." AHEA: E-Journal of the American Hungarian Educators Association (2010) http://ahea.net/e-journal/volume-3-2010/4

Vasvári, Louise O., and I-Chun Wang, eds. Forthcoming. "Holocaust Cookbooks as Communal Partial Autobiography." War and Life Writing.

Vogel, Miriam L. 1994. "Gender as a Factor in the Transgenerational Transmission of Trauma." Women and Therapy 5.2: 35-47.

Young, James L. 1987. "Interpreting Literary Testimony: A Preface to Reading Holocaust Diaries and Memoirs." New Literary History 18.2: 403-423.

Zelizer, Barbie. 1998. Remembering to Forget. Holocaust Memory through the Camera's Eye. Chicago: The U of Chicago P. 